\title{
Lipidic characterization of Santa Inês lamb shoulder
}

\author{
Caracterização lípidica da paleta de cordeiros Santa Inês
}

\author{
Christian Albert Carvalho da CRUZ ${ }^{1}$, Cristiane Leal dos SANTOS-CRUZ ${ }^{1 *}$, \\ Carmen Josefina Contreras CASTILLO ${ }^{2}$, Alexilda Oliveira de SOUZA ${ }^{3}$, \\ Lílian Borges da SILVA ${ }^{1}$, Priscila Nunes BRITO²
}

\begin{abstract}
The edible portion of the shoulder of 12 castrated and 12 non-castrated Santa Inês lambs slaughtered at different ages (84, 168, 210, 252 days) were used. The shoulders were chemically analyzed to determine the quantity of total lipids, cholesterol, and fatty acids composition. Castrated and non-castrated lambs gained body weight $(\mathrm{p}=0.0393, \mathrm{p}=0.0017)$ and half carcass weight $(\mathrm{p}=0.0240, \mathrm{p}=0.0017)$, respectively. The shoulder weight was increased in the carcasses of non-castrated lambs $(\mathrm{p}=0.0110)$. The edible portion of the shoulder of castrated lambs presented higher total lipids $\left(16.09 \mathrm{~g} .100 \mathrm{~g}^{-1}\right)$. The cholesterol content was influenced by castration $(\mathrm{p}=0.0001)$ reducing with age. Castrated animals presented higher content of C18:1 T11, CLA, and C18:0. The shoulder weight is only increased with increasing age in the carcasses of non-castrated lambs. Castration influences the cholesterol content of the shoulder; however, both castrated and non-castrated lambs had their cholesterol contents reduced with increasing age. Castration and age interfered in the estearic acid concentration of the edible portion of lamb shoulder.
\end{abstract}

Keywords: cholesterol; fatty acids; lambs; lipids; shoulder.

\section{Resumo}

Foi utilizada a porção comestível da paleta de cordeiros Santa Inês de 12 castrados e 12 não castrados, abatidos em diferentes idades (84, $168,210,252$ dias). Obteve-se o peso da meia carcaça e as paletas foram pesadas e armazenadas a $-5^{\circ} \mathrm{C}$. A porção comestível (músculo e gordura) foi analisada quimicamente para determinação da quantidade de lipídios totais, teores de colesterol e perfil de ácidos graxos. Cordeiros castrados e não castrados aumentaram o peso corporal $(p=0,0393 ; p=0,0017)$ e peso da meia carcaça $(p=0,0240 ; p=0,0017)$, respectivamente. O peso da paleta foi incrementado nas carcaças dos ovinos não castrados $(\mathrm{p}=0,0110)$. A porção comestível da paleta dos animais castrados apresentou maior quantidade de lipídios totais $\left(16,09 \mathrm{~g} .100 \mathrm{~g}^{-1}\right)$. O teor de colesterol foi influenciado pela castração $(\mathrm{p}=0,0001)$, reduzindo com a idade. Cordeiros castrados apresentaram maior quantidade de C18:1 T11, CLA e C18:0. A castração influencia o conteúdo de colesterol da paleta; entretanto, tanto cordeiros castrados quanto não castrados tiveram o conteúdo de colesterol reduzido com o aumento da idade. A castração e a idade interferiram na concentração de ácido esteárico da porção comestível da paleta de cordeiros. Palavras-chave: colesterol; ácidos graxos;cordeiros; gordura; paleta.

\section{Introduction}

Knowing the chemical composition of meat is very important for elucidating its nutritional value, as well as for providing information that is useful for determining diets adequate to specific population groups. Physicochemical characteristics of lamb meat are relevant since it is a healthy meat. However, its nutritional value is underexploited and little studied, preventing its importance to be proved, thus contributing with medicine when it comes to reducing diseases development.

The lamb market has evolved a lot in the last years, and although meat sheep husbandry is still an activity of little economic expression in the Brazilian livestock agribusiness scenario, its production has been increasing year after year. With total intake increase to 120 thousand tons, in 2007, there was an increase of per capita intake of lamb in Brazil, from stagnated $0.46 \mathrm{~kg} /$ person/year to $0.7 \mathrm{~kg} /$ person/year (FOOD..., 2008). However, this intake oscillates a lot, reaching values of $15 \mathrm{~kg} /$ person/year, depending on the region of the country.

The preference for lamb meat is influenced by usual aspects, such as looking for a soft meat with low fat and high muscle content. However, there is a necessity of clearer definition of saturated fatty acids composition, especially in the edible portion of the cuts, which are myristic, palmitic, and stearic acids the most common ones found in lamb.

\footnotetext{
Received 4/10/2009

Accepted 14/2/2010 (004449)

Departamento de Tecnologia Rural e Animal/UECO/EPOC, Universidade Estadual do Sudoeste da Bahia - UESB, Rod. BR 415, Km 03, s/n, CEP 45700-000,

Itapetinga - BA, Brasil, E-mail: cris.leal@click21.com.br

2 Agroindústria, Alimentos e Nutrição, Escola Superior de Agricultura “Luiz de Queiroz" - ESALQ, Universidade de São Paulo - USP, CEP 13418-900, Piracicaba - SP, Brasil

${ }^{3}$ Departamento de Estudos Básicos - DEBI, Universidade Estadual do Sudoeste da Bahia - UESB, CEP 45700-000, Itapetinga - BA, Brasil

${ }^{4}$ Faculdade de Economia, Administração e Contabilidade da Universidade de São Paulo - FEA/USP, Universidade Estadual de Campinas - UNICAMP, Campinas - SP, Brasil

${ }^{*}$ Corresponding author
} 
Considering that lamb meat has commercial value, both in the national and international market, due to economic and social characteristics, besides the lack of scientific information about its lipidic composition, the objective of the present study was to determine total lipids, cholesterol, and fatty acids composition of the edible portion of Santa Inês lamb shoulder from 12 castrated and 12 non-castrated animals, which were slaughtered at different ages (84, 168, 210, 252 days) and submitted to semi-intensive regime.

\section{Materials and methods}

\subsection{Location, lodgment, and animals}

The experiment was conducted at the Goats and Sheep Experimental Station (UECO) of the Southwest State University of Bahia (Uesb), Itapetinga campus, BA, Brazil, and at the Experimental Station of the Company of Agricultural Development of Bahia (EBDA), Jequié, BA, Brazil. Twelve castrated and twelve non-castrated lambs were slaughtered at four different ages (84, 168, 210, 252 days); three lambs per slaughter age were used. The animals were castrated when they were one month old and weaned at 84 days. They were submitted to semi-intensive production system, with pasturing at day time, in areas cultivated with Green panic, Panicum maximum and Brachiaria decumbens grasses and supplemented with mineral salt and concentrated with $22 \%$ of crude protein, which was offered at $2.2 \%$ of body weight ratio and divided into two daily meals. During the cold period, from June to October, when the pasture quality decreases, a supplementation with a multiple mixture, which is a mineral supplement containing protein and energy, was offered to the animals.

\subsection{Lambs' slaughtering}

The slaughtering procedure was conducted according to the methods recommended by the Brazilian Agricultural Ministry (BRASIL, 1997) when the lambs achieved the pre-established ages. They were submitted to $16 \mathrm{~h}$ of solid food fasting, and next they were weighed for obtaining the slaughter weight (SW).

At the time of slaughter, under veterinary-sanitary supervision, the animals were submitted to stunning by cerebral concussion. Next, the bleeding was done by severing the carotid and jugular veins; the blood was recovered and weighed. The evisceration was then performed and the carcass was obtained. After cleaned and weighed, it was taken to the chilling camera, at $(2 \pm 0.5)^{\circ} \mathrm{C}$, for a $24 \mathrm{~h}$ period. The half carcass weight (HCW) was then obtained; the shoulders were taken from the left half carcasses only, adding, therefore, three cuts per lamb age. The shoulders were weighed and stored in freezer at $-5{ }^{\circ} \mathrm{C}$ for later dissection and recovery of the edible portion (muscle and fat) to be chemically analyzed in order to determine total lipids, cholesterol content, and fatty acids composition.

The shoulder was the cut selected because of the quantity of muscular and adipose tissues, and hypothetically, with no scientific proof, it possesses fatty acids that promote the rancidity of lamb meat, besides being considered a first or second category cut, depending on the cut system adopted. In the present experiment, the cut system developed by Santos (1999) was adopted considering the shoulder a second category cut. Besides the shoulder, other cuts can be used to infer the characteristics of lamb meat since they represent distinct anatomic regions, and present different physicochemical compositions due to the different synthesis and nutrient deposition rates on the tissues (SANTOS, 1999; 2002).

The cuts (shoulders) of castrated and non-castrated lambs, at different ages, were taken off the freezer 12 hours before the dissection was initiated; the defrost process occurred at environment temperature. The cuts were then individually weighed again. With dissection, i.e., separation of tissue components (bone, muscle, fat, and other tissues) of each cut using a scalpel and knife, the edible portion (muscle and fat) used for chemical analysis was obtained. The subcutaneous, intramuscular, and intermuscular fats were milled together, which are considered part of the edible portion. Similarly, the muscle milled with the fat was represented by all the muscles that compose the shoulder.

The edible portion of each shoulder, obtained from left half carcasses, was milled separately in an electric meat mill (10 opening with $8 \mathrm{~mm}$ disc). Next, a sample of the edible portion weighing 100 to 200 g per shoulder per age was separated from the total. The size of the samples varied due to the size of the cuts of the 84-day old animals. The samples were frozen at $-5{ }^{\circ} \mathrm{C}$ for later analysis of total lipids, cholesterol and fatty acids, which were performed in triplicate.

\subsection{Total lipids determination}

Total lipids or total fat determination was done at the Laboratory of Chemical Analyzes of the Goats and Sheep Experimental Station (UECO) of UESB, Itapetinga campus, BA, Brazil.

Total lipids or total fat of the edible portion of each shoulder was determined by Soxhlet extraction, using 1.0-2.0 g of natural matter sample, in triplicate. According to the methodology of Santos (2002), adapted from Silva (1981), the samples were inserted in a germitex paper thimble holder, and partially defatted with ethyl ether in a hermetically sealed recipient. After 12 hours, the samples were removed from the recipient and put in an oven at $105^{\circ} \mathrm{C}$ for obtaining the dry weight of the partially defatted sample, which was put in the Soxhlet extractor for obtaining the residual fat. The total fat was obtained by adding partial and residual fats.

\subsection{Cholesterol determination}

The extraction and reading of the cholesterol amount present in the edible portion of the shoulder was conducted at the Laboratory of Quality and Meat Processing and at the Laboratory of Biochemistry and Instrumental Analysis, of the Superior School of Agriculture "Luiz de Queiroz" (ESALQ/USP).

The cholesterol content was determined by the direct saponification method, using $2 \%$ of $\mathrm{KOH}$ in $50 \mathrm{~mL}$ of absolute ethanol, with adaptations (MAZALLI; SALDANHA; BRAGAGNOLO, 2003). Next, the reading was done in a HPLC, 
with automatic injector (SIL- 10AF - SHIMADZU AUTO SAMPLER), coupled to a diode array detector at $120 \mathrm{~nm}$. The HPLC was equipped with a C18 reverse phase column $(250 \times$ $4.6 \mathrm{~mm}$ ) with particle size of $5 \mu \mathrm{m}$. The mobile phase was composed of acetonitrile: isopropanol $(85: 15, \mathrm{v} / \mathrm{v})$ at isocratic flow rate of $1.5 \mathrm{~mL} /$ minuto. The column was kept at $35^{\circ} \mathrm{C}$, and the chromatograms were analyzed using a specific software. The results were expressed in $\mathrm{mg} .100 \mathrm{~g}^{-1}$.

\subsection{Fatty acids composition determination}

The extraction, methylation, and reading steps for determining the fatty acids composition of the edible portion of the shoulder were conducted at the Laboratory of Animal Nutrition of the Superior School of Agriculture "Luiz de Queiroz" (ESALQ/USP) using the methodology of Christie (1982) and Hara and Radin (1978).

In order to determine the fatty acids composition, the lipids extraction was done according to the method described by FOLCH et al. (1957). The fatty acids were transformed in fatty acid esters using the method of Hartman and Lago (1973), which was further analyzed using a Focus GC - Finnigan, with flame-ionization detector, equipped with a capillary column CP-Sil 88 (Varian), measuring $100 \mathrm{~m}$ of length by $0.25 \mathrm{~mm}$ of diameter by $0.20 \mu \mathrm{m}$ of film thickness. Hydrogen was the carrier gas at $1.8 \mathrm{~mL} /$ minute flow rate. The oven temperature program was: $70^{\circ} \mathrm{C}$ at the beginning, hold for 4 minutes, $175^{\circ} \mathrm{C}$ $\left(13^{\circ} \mathrm{C} /\right.$ minute $)$, hold for 27 minutes, $215^{\circ} \mathrm{C}\left(4^{\circ} \mathrm{C} /\right.$ minute $)$, hold for 9 minutes, and $230^{\circ} \mathrm{C}\left(7^{\circ} \mathrm{C} /\right.$ minute $)$, hold for 5 minutes; the total time was $65 \mathrm{~min}$. The injector and detector temperatures were $250{ }^{\circ} \mathrm{C}$ and $300{ }^{\circ} \mathrm{C}$, respectively. A $1 \mu \mathrm{L}$ aliquot of the esterified extract was injected in the chromatographer. The identification of the fatty acids was done comparing the retention times of methyl esters with butter fatty acid standards (BCR-CRM 164, Anhydrous Milk-Fat Producer: BCR Institute for Reference Materials and Measurements; Supelco TM Component FAME Mix, cat 18919 Supelco, Bellefonte, PA). The fatty acid percentages were obtained using the software Chromquest 4.1 (Thermo Electron, Italy).

The fatty acid composition was identified and quantified in area percentage, being SFA (sum of mean peak area percentages of saturated fatty acids), UFA (sum of mean peak area percentages of unsaturated fatty acids), MUFA (sum of mean peak area percentages of monounsaturated fatty acids), PUFA (sum of mean peak area percentages of polyunsaturated fatty acids), SFA:UFA ratio, MUFA:PUFA ratio, and Hyper:Hypo ratio (hypercholesterolemic fatty acids $(\mathrm{C} 14: 0+\mathrm{C} 16: 0)$ to hypocholesterolemic fatty acids (MUFA + PUFA).

\subsection{Statistical analysis}

A completely randomized design in a $4 \times 2$ factorial design, which consisted of 4 different ages (84, 168, 210, 252 days) and two sexual conditions (castrated and non-castrated) was used. For each age, three shoulders of the left half carcass were used, and the experimental unit was composed by one animal. To study the effect of castration, age, and the interaction between castration and age, the PROC GLM procedure of
SAS (Statistical..., 2000) software was used considering the following statistical model: $\mathrm{Y}_{\mathrm{ijk}}=\mathrm{m}+\mathrm{a}_{\mathrm{i}}+\mathrm{b}_{\mathrm{j}}+(\mathrm{ab})_{\mathrm{ij}}+\mathrm{e}_{(\mathrm{ij}) \mathrm{k}}$; where: $\mathrm{Y}_{\mathrm{ijk}}=$ values observed for the $\mathrm{i}$-th sexual condition and $\mathrm{j}$-th slaughter age, at $\mathrm{k}$ repetition; $\mathrm{m}=$ effect of mean; $\mathrm{a}_{\mathrm{i}}=$ effect of $i$ sexual condition $(i=1,2) ; b_{i}=$ effect of $j$ age at slaughter $(j=1,2,3,4)$; and $(a b)_{i j}=$ effect of interaction between $i$ sexual condition and $\mathrm{j}$ age at slaughter; $\mathrm{e}_{(\mathrm{i}) \mathrm{k}}=$ random error when observing $\mathrm{Y}_{\mathrm{ijk}}$.

\section{Results and discussion}

The body weight was not influenced by the effect of castration $(p=0.5021)$, i.e. castrated and non-castrated Santa Inês lambs, in general, had their body weight altered with age in the same increasing proportion. However, at early development, 84 days, castrated lambs significantly outnumbered ( $\mathrm{p}=0.0457)$ noncastrated lambs in terms of body weight, $25.66 \mathrm{~kg}$ and $18.20 \mathrm{~kg}$, respectively. With increasing age, castrated and non-castrated lamb body weights presented linear increase $(\mathrm{p}=0.0001)$ (Table 1$)$ indicating the direct relation between age and weight.

Castrated lambs did not present greater body weight than non-castrated animals ( $\mathrm{p}=0.5021)$ despite the fact that castration causes absence of testosterone, which, according to Domingues (1968), would promote lower protein synthesis, and, consequently, accumulation of body fat increasing the body weight.

Castration is, therefore, unnecessary when the purpose is slaughtering production animals, i.e., when using lambs or young animals. The development of secondary characteristics in non-castrated males is attributed to the production of testosterone, a hormone that promotes muscular and skeletal growth, but it should be emphasized that this effect is intensified after puberty.

Osório et al. (1999), comparing castrated and non-castrated Hampshire Down $\times$ Corriedale crossbred lambs, slaughtered at 150 days old, did not find significant differences in slaughter weight. This result is in agreement with those found in the present work for 168,210 , and 252 days indicating that there is no need to castrate young animals for precocious stimulation of production characteristics.

Castrated animals possibly have the fat deposition intensified presenting better carcass conformation, which, in turn, presents a positive correlation with half carcass weight. However, despite the mean values that are $4 \%$ higher for castrated lambs when compared to non-castrated animals, the only significant difference $(\mathrm{p}=0.4000)$ in half carcass weight was observed at 84 days old.

On the other hand, at 252 days old, non-castrated lambs $(6.24 \mathrm{~kg})$ presented $25 \%$ greater $(\mathrm{p}=0.047)$ half carcass weight than castrated lambs $(4.63 \mathrm{~kg}$ ) (Table 1$)$. Thus, non-castrated lambs at 252 days and $33 \mathrm{~kg}$ of body weight present satisfactory development and/or growing rates because they are young animals, which use food more efficiently. They precociously present better partition of the diet nutrients to the tissues, which positively influences growth. Therefore, in the present study, there was no need for castration. 
Cruz et al.

Table 1. Mean values and respective standard error of body weight (BW), half carcass weight (HCW), and shoulder weight (SHW) of castrated (C) and non-castrated (NC) Santa Inês lambs at different ages.

\begin{tabular}{|c|c|c|c|c|c|c|}
\hline \multirow{3}{*}{$\begin{array}{l}\text { Effect of } \\
\text { castration }\end{array}$} & \multicolumn{4}{|c|}{ Slaughter age (days) } & \multirow[t]{3}{*}{ General X } & \multirow[t]{3}{*}{$\operatorname{Pr}>|t|$} \\
\hline & 84 & 168 & 210 & 252 & & \\
\hline & \multicolumn{4}{|c|}{ BW (kg) } & & \\
\hline $\mathrm{C}^{1}$ & $25.66^{(0.98) *}$ & $24.33^{(2.02)}$ & $29.53^{(2.32)}$ & $28.00^{(2.80)}$ & 26.88 & 0.5021 \\
\hline $\operatorname{Pr}>|t|$ & 0.0457 & 0.9848 & 0.5080 & 0.1661 & & $\operatorname{Pr}>|F|$ \\
\hline General X BW & 21.93 & 24.36 & 28.36 & 30.50 & 26.29 & 0.0001 \\
\hline $\begin{array}{l}\text { Effect of } \\
\text { castration }\end{array}$ & \multicolumn{4}{|c|}{ HCW (kg) } & General X & $\operatorname{Pr}>|t|$ \\
\hline $\mathrm{C}^{3}$ & $5.09^{(0.11) *}$ & $3.73^{(2.02)}$ & $5.35^{(2.32)}$ & $4.63^{(2.80)}$ & 4.70 & 0.6722 \\
\hline $\mathrm{NC}^{4}$ & $3.41^{(0.53)}$ & $4.01^{(0.46)}$ & $4.49^{(0.31)}$ & $6.24^{(0.93)}$ & 4.54 & - \\
\hline $\operatorname{Pr}>|t|$ & 0.400 & 0.7138 & 0.2667 & 0.047 & & $\operatorname{Pr}>|F|$ \\
\hline General X HCW & 4.25 & 3.87 & 4.92 & 5.43 & 4.62 & 0.0001 \\
\hline $\mathrm{NC}^{6}$ & $0.496^{(0.06)}$ & $0.633^{(0.08)}$ & $0.780^{(0.07)}$ & $0.891^{(0.10)}$ & 0.700 & - \\
\hline $\operatorname{Pr}>|t|$ & 0.0159 & 0.9876 & 0.9629 & 0.0965 & & $\operatorname{Pr}>|F|$ \\
\hline General X SHW & 0.639 & 0.632 & 0.782 & 0.798 & 0.725 & 0.0465 \\
\hline
\end{tabular}

According to Silva Sobrinho et al. (2005), castration is an unnecessary management practice in slaughter lambs' production systems because the stress caused has an adverse effect on growing rate. RIBEIRO et al. (2003) concluded that the castration method does not affect the animals' performance for termination at $30 \mathrm{~kg}$ of body weight corroborating the results found in the present experiment.

The shoulder weight of castrated lambs was greater $(\mathrm{p}=0.0159)$, at 84 days, than that of non-castrated lambs, thus, probably, the shoulder has the rate of development early on in animals subjected to castration after weaning. There was no difference in the shoulder weight between castrated and non-castrated animals at 168, 210, and 252 days. Therefore, the partition of ingested nutrients in castrated lambs is probably similar until they are 252 days old, which means that during this period there are no modifications in the development related to muscular, adipose, and bone tissues.

According to Silva (2005), the shoulder is a cut that presents later growth when compared to the body weight, thus, in castrated lambs, this cut should present greater weight after 252 days old. However, Santos (1999), working with noncastrated lambs, verified that the shoulder presents a growth rate proportional to the body weight, i.e., the shoulder weight increases with body weight and/or age. The same behavior was observed in the present study for non-castrates lambs' shoulder, which, at 84 days, weighed $0.496 \mathrm{~kg}$ and reached $0.891 \mathrm{~kg}$ at 252 days.
Castrated lambs presented, in the edible portion of the shoulder, elevated content of total lipids at 84,168 , and 210 days old (Table 2).

Total lipids values varied from 14.08 to $15.49 \%$ for castrated lambs and from 10.48 to $14.91 \%$ for non-castrated lambs indicating an increase of $10 \%$ and $30 \%$, respectively. These values are high when compared to the results found by Bonagurio, Perez and Garcia (2001), who described mean values of 1.0 to $3.5 \mathrm{~g} .100 \mathrm{~g} \mathrm{~g}^{-1}$ in lambs' muscles. However, it should be emphasized that in the present experiment, the contents were obtained from samples of the edible portion (muscle and fat) of the shoulder, instead of only one type of muscle.

Castrated lambs presented a mean value of $16.09 \mathrm{~g} .100 \mathrm{~g}^{-1}$ with significant effect $(p=0.0001)$ when compared to noncastrated lambs $\left(11.95 \mathrm{~g} .100 \mathrm{~g}^{-1}\right)$. This was probably caused by the metabolism, which requires a higher amount of fat on castrated lambs. This same result was observed by Kemp, Shelley and Ely (1972); however, according to Vergara, Molina and Gallego (1999), the difference between castrated and noncastrated animals, when it comes to the centesimal composition of the meat, is not so large, especially when the growth period studied is considered.

The lipid content of lamb meat presents large variation, especially as a function of age and sex (PÉREZ et al., 2002; ZEOLA et al., 2004; MADRUGA et al., 2005). The shoulder of castrated and non-castrated lambs presented lipid values higher than those determined by Madruga et al. (2005), who analyzed the leg cut. 
Pinheiro (2006), working with different sheep categories, wether ewe and lambs, found total lipid values lower than those found in the present experiment; however, the author used only the muscle of the shoulder (Triceps brachii), whereas, in the present work, the edible portion of the cut was used, i.e., muscle and fat.

Pinheiro (2006) found 9.16, 7.83, and 4.50\% of total lipids in wether, ewe and lamb muscles, respectively. In the present experiment, the values determined for the edible portion of the shoulder were 16.09 and $11.05 \mathrm{~g} .100 \mathrm{~g}^{-1}$ for castrated and non-castrated lambs, respectively. Therefore, castration induces lipid deposition on lambs' carcass cuts.

Castrated lambs presented higher cholesterol contents (72.52 mg.100 g $\left.\mathrm{g}^{-1}\right)$ in the edible portion of the shoulder than non-castrated lambs $\left(59.94 \mathrm{mg} .100 \mathrm{~g}^{-1}\right)$, for all ages $(\mathrm{p}=0.0001)$ (Table 3). Pinheiro (2006), when studying muscles from different sheep categories and cuts, verified that the cholesterol contents were influenced by animal categories (wethers $69.38 \mathrm{mg} .100 \mathrm{~g}^{-1}$, ewes $65.76 \mathrm{mg} .100 \mathrm{~g}^{-1}$, and lambs $\left.62.02 \mathrm{mg} .100 \mathrm{~g}^{-1}\right)$.

For Johnson et al. (1995), castration has no effect on the cholesterol content of goat meat; however, in the present experiment, when analyzing the edible portion of the shoulder, it can be stated that castration had effect $(\mathrm{p}=0.0001)$ on the cholesterol content of sheep meat inducing changes in composition with age because cholesterol is a complex lipidsteroid substance strongly present in animal fats. Therefore, the lambs castrated by hormone action have to deposit more fat in the meat with advancing age thus increasing the cholesterol content.

Total cholesterol content in lamb may vary significantly, and the sheep maturity is one of the factors responsible for that. Rebello (2003) argues that the variations in the cholesterol content, when considering several studies, may be related to feeding management, location of the samples collection, age, animals' breed, and to the methodology used for determination.

Castration positively influenced the cholesterol content in the shoulder; on the other hand, both castrated and noncastrated lambs had their shoulder cholesterol content reduced with age. Santos-Filho et al. (2005), working with goats, a species with similar characteristics to sheep, obtained results to similar those found in the present experiment. Castrated and non-castrated goats presented significant difference, when Longissimus dorsi was analyzed, and the cholesterol content in castrated goats was $63.75 \mathrm{mg} .100 \mathrm{~g}^{-1}$ and $54.37 \mathrm{mg} .100 \mathrm{~g}^{-1}$ in non-castrated goats. These values were close to the ones obtained in the present experiment for the edible portion of castrated lambs.

The castration effect on lauric acid (C12:0), myristic acid (C14:0), pentadecanoic acid (C15:0), oleic acid (C18:1 C9), vaccenic acid (C18:1 C11), linoleic acid (C18:2 C9 C12), and conjugated linoleic acid (C18:2 C9 T11 - CLA) percentages (Table 4), indicates that castrating young animals (lambs) probably induces the production of saturated fatty acids, which is responsible for the increase of cholesterol levels in the shoulder. These fatty acids were also influenced by the slaughter age, together with myristoleic acid (C14:1 C9).

The presence of those fatty acids in the lipids of the edible portion of the shoulder influences the nutritional quality of lamb meat. It can be observed the degrees of saturation and unsaturation of the fatty acids existent in the shoulder and their induction to a higher or lower meat quality. According to Mahgoub et al. (2002), the higher the degree of saturation, the lower the meat quality. This is due to the negative effects to the human health besides the fact that the quality is directly influenced by the composition of the fatty acids present in lipids.

For both castrated and non-castrated lambs, there was effect of slaughter age on estearic acid (C18:0) percentage in the

Table 2. Mean values of total lipids ( $\left.\mathrm{g} .100 \mathrm{~g}^{-1}\right)$ and respective standard error, in castrated (C) and non-castrated (NC) Santa Inês lambs' shoulder, at different ages.

\begin{tabular}{|c|c|c|c|c|c|c|}
\hline \multirow[t]{2}{*}{ Effect of castration } & \multicolumn{4}{|c|}{ Slaughter age (days) } & \multirow[t]{2}{*}{ General X } & \multirow[t]{2}{*}{$\operatorname{Pr}>|t|$} \\
\hline & 84 & 168 & 210 & 252 & & \\
\hline $\mathrm{C}$ & $15.49^{(0.97) \star *}$ & $18.58^{(1.11) * *}$ & $16.22^{(2.17) *}$ & $14.08^{(0.39)}$ & $16.09^{\star *}$ & 0.0001 \\
\hline $\mathrm{NC}$ & $10.48^{(0.20)}$ & $10.91^{(0.47)}$ & $11.49^{(0.24)}$ & $14.91^{(1.79)}$ & 11.95 & - \\
\hline $\operatorname{Pr}>|t|$ & 0.0073 & 0.0002 & 0.0104 & 0.6149 & - & $\operatorname{Pr}>|F|$ \\
\hline General X & 12.99 & 14.74 & 13.85 & 14.49 & 14.02 & 0.0013 \\
\hline
\end{tabular}

${ }^{* *} \mathrm{p}<0.01 ;{ }^{*} \mathrm{p}<0.05 . \mathrm{C}: \mathrm{y}^{\prime}=6.19+0.15 \mathrm{x}-0.0004 \mathrm{X}^{2}\left(\mathrm{R}^{2}=84.86\right)$ with $\mathrm{p}=0.0374 . \mathrm{NC}: \mathrm{y}^{\prime}=7.87+0.022 \mathrm{X}\left(\mathrm{R}^{2}=78.74\right)$ with $\mathrm{p}=0.0162 . \mathrm{N}$ total $=24$.

Table 3. Mean values of cholesterol (mg. $100 \mathrm{~g}^{-1}$ ) and respective standard error, in castrated (C) and non-castrated (NC) Santa Inês lambs' shoulder at different ages.

\begin{tabular}{|c|c|c|c|c|c|c|}
\hline \multirow[t]{2}{*}{ Effect of castration } & \multicolumn{4}{|c|}{ Slaughter age (days) } & \multirow[t]{2}{*}{ General X } & \multirow[t]{2}{*}{$\operatorname{Pr}>|\mathrm{t}|$} \\
\hline & 84 & 168 & 210 & 252 & & \\
\hline $\mathrm{C}$ & $75.30^{(2.73) * *}$ & $71.48^{(0.95) \star *}$ & $74.91^{(0.32) \star *}$ & $68.38^{(2.56) * *}$ & $72.52^{\star *}$ & 0.0001 \\
\hline $\mathrm{NC}$ & $62.74^{(0.88)}$ & $58.72^{(2.02)}$ & $64.30^{(0.09)}$ & $53.94^{(1.28)}$ & 59.94 & - \\
\hline $\operatorname{Pr}>|\mathrm{t}|$ & 0.0001 & 0.0001 & 0.0003 & 0.0001 & - & $\operatorname{Pr}>|F|$ \\
\hline General X & 69.02 & 65.10 & 69.60 & 61.19 & 66.23 & 0.0001 \\
\hline
\end{tabular}

${ }^{* *} \mathrm{p}<0.01 . \mathrm{C}: \mathrm{y}^{\prime}=78.08-0.031 \mathrm{X}\left(\mathrm{R}^{2}=47.43\right)$ with $\mathrm{p}=0.0313 . \mathrm{NC}: \mathrm{y}^{\prime}=66.32-0.035 \mathrm{X}\left(\mathrm{R}^{2}=33.51\right)$ with $\mathrm{p}=0.0125 . \mathrm{N}$ total $=24$. 
edible portion of the shoulder. On the other hand, oleic acid (C18:1 C9) sulphide influence of castration, but not of slaughter age. According to Shaeffer and Brousseau (1998), estearic acid is rapidly converted into oleic acid by the organism; however, in the present experiment, it can be stated that there is not a conversion relation between these acids since there was no influence of castration and age on their percentages.

Considering the effect of slaughter age, stearic acid (C18:0) of the edible portion of the shoulder adjustment quadratic, when the lambs, castrated and intact, were in the range from 210 to 252 days of age. Perez et al. (2002) verified that C18:0 percentage decreased linearly with body weight in Santa Inês lambs and was adjusted to a quadratic equation with maximum point at $35 \mathrm{~kg}$ in Bergamácia lambs.

As for capric (C10:0), heptadecanoic (C17:0), linderic (C12:1), pentadecanoic (C15:1), cis-10-heptadecanoic (C17:1), palmitoleic (C16:1 C9), $\gamma$-linolenic (C18:3 $\omega 6), \alpha$-linolenic (C18:3 $\omega 3$ ), eicosapentaenoic (C20:5 $\omega 6)$, and docosahexaenoic (C20:6 $\omega 3$ ) acid percentages, there was no effect of castration or age on their composition in the edible portion of the shoulder of Santa Inês lambs up to 252 days old. Nevertheless, there was interaction of the effects for lauric (C12:0), myristic (C14:0), palmitic (C16:0), estearic (C18:0), and myristoleic (C14:1 C9) acids, i.e., considering fatty acid composition, the saturated fatty acid composition of the edible portion of the shoulder changes when the lambs are castrated and increase their age.
Since Triceps brachi is one of the muscles from the lamb's shoulder, the results found in the present research can be compared with the results found by Gallo, Siqueira and Rosa (2007), who determined, in decreasing order, the main fatty acids present in the intramuscular fat of Triceps brachi muscle. They found influence of the termination system on oleic (C18:1), palmitic (C16:0), and estearic (C18:0) acids, which is in agreement with the results found for castrated and non-castrated lambs, except that in the present experiment the influence was by the slaughter age.

Tejeda, Peña and Andres (2008), working with Merino breed male and female animals, analyzed longissiums and semimembranosus muscles finding C18:1 fatty acid as the major component of the fat, followed by C16:0 and C18:0. This observation was similar to the findings of Sañudo et al. (2000), who worked with Merino lambs, and Cañeque et al. (2005) and Velasco et al. (2004), who worked with Spanish breeds.

Pérez et al. (2002) evaluating the effect of the slaughter weight of Santa Inês and Bergamácia lambs on the fatty acid composition, cholesterol content, and chemical properties identified 12 fatty acids and reported that palmitic acid (C16:0) increased linearly with body weight.

Essential fatty acids, $\gamma$-linolenic (C18:3 $\omega 6)$ and $\alpha$-linolenic (C18:3 $\omega 3)$, are precursors of eicosatetraenoics acids (C20:4); however, only traces of these acids were detected in the edible portion of the shoulder, probably because C18:3 $\omega 6$ and $\mathrm{C} 18: 3 \omega 3$ percentages were insufficient for the enzymatic

Table 4. Fatty acid composition (area percentage) in castrated (C) and non-castrated (NC) Santa Inês lambs' shoulder at different ages.

\begin{tabular}{|c|c|c|c|c|c|c|c|}
\hline \multirow[t]{2}{*}{ Fatty acids ${ }^{\mathrm{a}}$} & \multicolumn{4}{|c|}{ Slaughter age (days) } & \multirow[t]{2}{*}{ Castration } & \multirow[t]{2}{*}{ Slaughter age } & \multirow{2}{*}{$\begin{array}{c}\text { Castration } \\
\text { Age }\end{array}$} \\
\hline & 84 & 168 & 210 & 252 & & & \\
\hline C10:0 & 0.2650 & 0.2550 & 0.3021 & 0.2390 & ns & ns & ns \\
\hline C12:0 & 0.9373 & 0.7411 & 0.5776 & 0.4146 & * & $\star$ & $\star$ \\
\hline C15:0 & 1.0116 & 1.1146 & 1.0533 & 1.0851 & * & ns & ns \\
\hline C16:0 & 26.4403 & 25.2041 & 26.3158 & 24.0710 & ns & ns & $*$ \\
\hline C12:1 & 0.1291 & 0.0995 & 0.0846 & 0.1568 & ns & ns & ns \\
\hline C15:1 & 0.0385 & 0.0325 & 0.0161 & 0.0821 & ns & ns & ns \\
\hline $\mathrm{C} 17: 1$ & 0.6498 & 0.6468 & 0.6548 & 0.6773 & ns & ns & ns \\
\hline C14:1 C9 & 0.1943 & 0.1566 & 0.1763 & 0.1453 & ns & ns & * \\
\hline C16:1 C9 & 1.9933 & 2.0093 & 2.0168 & 1.8230 & ns & ns & ns \\
\hline $\mathrm{C} 18: 3 \omega 6$ & 0.0790 & 0.1546 & 0.1111 & 0.1126 & ns & ns & ns \\
\hline $\mathrm{C} 18: 3 \omega 3$ & 0.5543 & 0.5776 & 0.4286 & 0.6151 & ns & ns & ns \\
\hline C18:2 C9 T11 ${ }^{\mathrm{b}}$ & 1.2301 & 0.9028 & 1.0106 & 1.0538 & * & ns & ns \\
\hline C20:5 $\omega 6$ & 0.1975 & 0.1720 & 0.2803 & 0.2438 & ns & ns & ns \\
\hline $\mathrm{C} 22: 6 \omega 3$ & 0.1133 & 0.0610 & 0.0410 & 0.0751 & ns & ns & ns \\
\hline
\end{tabular}

${ }^{\mathrm{a}} \mathrm{C} 10: 0=$ capric acid; $\mathrm{C} 12: 0=$ lauric acid; $\mathrm{C} 14: 0=$ myristic acid; $\mathrm{C} 15: 0=$ pentadecanoic acid; $\mathrm{C} 16: 0=$ palmitic acid; $\mathrm{C} 17: 0=$ heptadecanoic acid; $\mathrm{C} 18: 0=$ estearic acid; $\mathrm{C} 12: 1=$ linderic or lauroleic acid; $\mathrm{C} 15: 1=$ 5-pentadecanoic acid; $\mathrm{C} 17: 1=$ cis-10-heptadecanoic acid; $\mathrm{C} 14: 1 \mathrm{C} 9=$ myristoleic acid; $\mathrm{C} 16: 1 \mathrm{C} 9=$ palmitoleic acid; $\mathrm{C} 18: 1 \mathrm{C} 9=$ oleic acid; $\mathrm{C} 18: 1 \mathrm{C} 11=$ vaccenic acid; $\mathrm{C} 18: 2 \mathrm{C} 9 \mathrm{C} 12=$ linoleic acid; $\mathrm{C} 18: 3 \omega 6=\gamma$-linolenic acid; $\mathrm{C} 18: 3 \omega 3=\alpha$-linolenic acid; $\mathrm{C} 20: 5 \omega 6=\mathrm{EPA}$ (eicosapentaenoic acid); $\mathrm{C} 22: 6 \omega 3=$ docosahexaenoic acid $(\mathrm{DHA}) . \mathrm{ns}=$ not significant; ${ }^{\mathrm{b}}$ conjugated linoleic acid (CLA). ${ }^{*}$ significant at $5 \%$ probability. 
complexes to perform the biosynthesis. Since the lambs were raised in the pasture, forage must have not been rich enough in these fatty acids, so that they could be transported by the blood as triglycerides and deposited in storage tissues and other structural lipids.

Castrated lambs presented higher percentages of C15:0, C18:1 C11, and CLA acids, whereas non-castrated lambs presented, in the edible portion of the shoulder, higher percentages of C12:0, C14:0, C18:1 C9, and C18:2 C9 C12. Monounsaturated fatty acids, C18:1 C9, and CLA were found in the shoulder of non-castrated Santa Inês lambs, especially C18:1 $\mathrm{C} 9$, which was determined in high concentrations in the edible portion of castrated $(24.18 \%)$ and non-castrated (27.29\%) lambs (Table 5). This allows us to state that the intake of the edible portion of the shoulder may reduce serum cholesterol because it presents a high content of oleic acid. Tejeda et al. (2008) found that Longissimus dorsi muscle of male and female Merino lambs presented different proportions of C12:0, C14:0, C16:0, and C18:1, which was the same behavior observed in the present experiment for castrated and non-castrated Santa Inês lambs.

Myristic acid (C14:0), the main responsible for the increase in serum cholesterol concentration (HAYES et al., 1991), was determined as representing $5.76 \%$ and $6.96 \%$ of fat in the edible portion of the shoulder of castrated and non-castrated lambs, respectively (Table 5). Non-castrated lambs presented, in general, lower cholesterol contents $\left(59.94 \mathrm{mg} .100 \mathrm{~g}^{-1}\right)$ than castrated lambs $\left(72.52 \mathrm{mg} .100 \mathrm{~g}^{-1}\right)(\mathrm{p}=0.0001)$. On the other hand, castrated lambs presented higher amount of total lipids in the edible portion of the shoulder $\left(16.09 \mathrm{~g} .100 \mathrm{~g} \mathrm{~g}^{-1}\right)$. Therefore, according to the mean values found, the presence of myristic acid in the shoulder does not result in increased cholesterol levels. For Moloney et al. (2001), palmitic (16:0) and myristic (14:0) acids can increase cholesterol synthesis and favor the accumulation of low density lipoproteins, which represents a risk factor for the development of cardiac diseases. In addition, the presence of high concentrations of myristic acid in the shoulder of sheep and goats is responsible for the characteristic flavor of the meat contributing to the rancidity aroma.

It can be observed that the presence of elevated values of C14:0 were found in the shoulder of non-castrated lambs, which, probably, may be an explanation for the unpleasant rancidity aroma of this cut.
Castrated lambs presented higher CLA concentration $(1.15 \%)$ than non-castrated lambs $(0.94 \%)(\mathrm{p}=0.0286)$ with no influence of slaughter age. Therefore, the shoulder intake of castrated lambs until 252 days old is recommended since carcinogenic actions in the organism will not take place. This is because conjugated linoleic acid (CLA) is a mixture of geometric and positional isomers of octadecadienoic acid with conjugated double bounds, which has been considered benefic for human health due to its anticancerous and metabolic properties.

There was influence of castration and age on linoleic acid concentration, and, therefore, on vaccenic acid concentration; castrated lambs presented higher concentration of C18:1 T11 $(1.68 \%)$ than non-castrated lambs, which, in turn, presented higher C18:2 C9 C12 concentration (1.67\%) than castrated animals $(1.34 \%)(\mathrm{p}=0.0355)$. Nevertheless, lambs with higher C18:1 T11 concentrations (1.68\%) in the shoulder, also presented higher CLA concentrations. This means that castrated lambs hydrolyzed better the ester bounds of dietetic lipids, which is followed by biohydrogenation of linoleic acid by ruminal bacteria and consequent CLA production. CLA production depends on ruminal biohydrogenation of linoleic (C18:2 C9 $\mathrm{C} 12)$ and linolenic (C18:3) acids, and, endogenously, CLA is produced from vaccenic acid (C18:1 T11), an intermediary of biohydrogenation.

There was no effect of castration on the total percentages of saturated fatty acids (SFA), unsaturated fatty acids (UFA), monounsaturated fatty acids (MUFA), and polyunsaturated fatty acids (PUFA) (Table 6). There was no effect of castration for SFA:UFA, PUFA:MUFA, and $\omega 6: \omega 3$ ratios either. However, there was quadratic effect of slaughter age on UFA and MUFA percentages with inflexion point at 182.5 days old for UFA; therefore, this is the age when the edible portion of the shoulder presents a mean concentration of $37.50 \%$ of UFA.

At 169.5 days old, there was higher concentration of MUFA, and the mean value of $34.96 \%$ was found in the shoulder of castrated and non-castrated lambs Pérez et al. (2002), working with Santa Inês and Bergamácia lambs, verified that the total percentage of saturated fatty acids was similar for all slaughter ages and breeds. Tejeda et al. (2008), analyzing Longissimus dorsi muscle of male and female Merino lambs, verified that the total saturated fatty acids was proportionally higher than the total monounsaturated fatty acids, followed by the total polyunsaturated fatty acids.

Table 5. Castration effect on the fatty acid composition (are percentage) of Santa Inês lambs' shoulder.

\begin{tabular}{|c|c|c|c|c|}
\hline Fatty acids & Castrated & Non-castrated & Mse & $\operatorname{Pr}>|\mathrm{t}|$ \\
\hline C12:0 & 0.5688 & $0.7665^{\star \star}$ & 0.0459 & 0.0077 \\
\hline C14:0 & 5.7635 & $6.9675^{\star}$ & 0.3816 & 0.0404 \\
\hline $\mathrm{C} 15: 0$ & $1.1197^{\star}$ & 1.0126 & 0.0311 & 0.0272 \\
\hline C18:1 C9 & 24.1817 & $27.2901^{\star *}$ & 0.6799 & 0.0052 \\
\hline C18:1 C11 & $1.6836^{* *}$ & 0.9645 & 0.1018 & 0.0001 \\
\hline C18:2 C9 C12 & 1.3456 & $1.6785^{\star}$ & 0.2318 & 0.0355 \\
\hline C18:2 C9 T11 & $1.1585^{\star}$ & 0.9401 & 0.0642 & 0.0286 \\
\hline
\end{tabular}

${ }^{a}$ conjugated linoleic acid (CLA). ${ }^{\mathrm{b}} \mathrm{C} 12: 0=$ lauric acid; $\mathrm{C} 14: 0=$ myristic acid; $\mathrm{C} 15: 0=$ pentadecanoic acid; C18:1 C9 = oleic acid; C18:1 C11 = vaccenic acid; C18:2 C9 C12 = linoleic acid. Mse $=$ Standard error of mean value. $\left({ }^{* *}\right)=$ significant at $1 \%$ probable. 
Table 6. Proportion of different fatty acids groups in the shoulder of castrated (C) and non-castrated (NC) Santa Inês lambs at different slaughter ages.

\begin{tabular}{|c|c|c|c|c|c|c|c|}
\hline \multirow[t]{2}{*}{ Fatty acids ${ }^{a}$} & \multicolumn{4}{|c|}{ Slaughter age (days) } & \multirow[t]{2}{*}{ Castration } & \multirow[t]{2}{*}{ Age } & \multirow{2}{*}{$\begin{array}{c}\text { Castration* } \\
\text { Age }\end{array}$} \\
\hline & 84 & 168 & 210 & 252 & & & \\
\hline SFA & 55.47 & 59.79 & 59.13 & 57.44 & ns & ns & ns \\
\hline UFA $^{1}$ & 41.44 & 37.09 & 38.21 & 39.02 & ns & * & ns \\
\hline UFA:SFA & 0.75 & 0.62 & 0.65 & 0.68 & ns & ns & ns \\
\hline MUFA $^{2}$ & 36.76 & 33.11 & 35.08 & 34.92 & ns & * & ns \\
\hline PUFA & 4.68 & 3.98 & 3.13 & 4.10 & ns & ns & ns \\
\hline PUFA:MUFA & 0.13 & 0.12 & 0.09 & 0.12 & ns & ns & ns \\
\hline$\omega 6: \omega 3$ & 0.13 & 0.28 & 0.27 & 0.21 & ns & ns & ns \\
\hline Hyper:Hypo ${ }^{3}$ & 0.11 & 0.10 & 0.09 & 0.06 & ns & * & ns \\
\hline
\end{tabular}

a SFA: saturated fatty acids; UFA = unsaturated fatty acids; UFA:SFA = unsaturated fatty acids (UFA) to saturated fatty acids (SFA) ratio; MUFA = monounsaturated fatty acids; PUFA = polyunsaturated fatty acids; PUFA:MUFA = polyunsaturated fatty acids (PUFA) to monounsaturated fatty acids (MUFA) ratio; $\omega 6: \omega 3=$ omega 6 to omega 3 polyunsaturated fatty acids ratio. ${ }^{3}$ hypercholesterolemic fatty acids $(\mathrm{C} 14: 0+\mathrm{C} 16: 0)$ to hypocholesterolemic fatty acids (monounsaturated + polyunsaturated) ratio. ${ }^{1} \mathrm{y}^{\prime}=50.83-0.146 \mathrm{x}+0.0004 \mathrm{x}^{2}$ $\mathrm{R}^{2}=94.97 .{ }^{2} \mathrm{y}^{\prime}=43.58-0.1017 \mathrm{x}+0.0003 \mathrm{x}^{2} \mathrm{R}^{2}=73.40 .{ }^{3} \mathrm{y}^{\prime}=0.14-0.0003 \mathrm{xR}^{2}=81.63$

Castration and slaughter age did not influence UFA:SFA ratio. Nevertheless, this ratio is based on the chemical structure of the fatty acids, which may not be the best way to evaluate the nutritional value of fat or the edible portion analyzed. Besides, when adding all the saturated and unsaturated fatty acids, it is supposed that they all act biochemically the same way; in the case of saturated fatty acids, it is supposed that they all induce the increase of cholesterol. This is not true since estearic acid (C18:0), for example, is denatured to oleic acid (monounsaturated fatty acid) so rapidly that it does not have effect on cholesterol increase. According to Monteiro (1998), estearic acid, differently from other saturated fatty acids, is classified as non atherogenic.

The $\omega 6: \omega 3$ acids ratio was taken into consideration due to the physiologic benefits that are attributed to them. On this aspect, the edible portion of the shoulder presented very low values, varying from 0.13 to 0.28 , in castrated and non-castrated lambs when compared to the values recommended by Freitas and Kietzer (2002), and Jones and Kubow (2003), who consider $4: 1$ or $5: 1$ the best ratio for $\omega 6: \omega 3$. Simopoulos (1991) considers the $\omega 6: \omega 3$ ideal ratio is 10:1 to 11:1. The Japan Society for Lipid Nutrition recommends using 4:1 $\omega 6: \omega 3$ ratio for healthy adults and 2:1 for the prevention of chronicle diseases in elder people (UAUY; MENA; VALENZUELA, 1999), whereas The World Health Organization recommends polyunsaturated $\omega 6: \omega 3$ fatty acids between 3:1 and 4:1 (NASCIMENTO; OYAMA, 2003).

Castrated and non-castrated lambs did not ingest $\omega 6$ and $\omega 3$ fatty acids, so that they would be oxidized and partitioned into the body tissues supplying energy, and, posterior identified in the edible portion of the shoulder of the studied lambs. However, the low concentration of $\omega 6$ and $\omega 3$, with the increasing age of the animals, does not indicate that the shoulder is not a healthy option for the human being in terms of developing brain tissue, visual function, and other benefits caused by omega ingestion. In addition, it is worthy to remember that the adequate ratio of these fatty acids in diets is still not clear.

\section{Conclusions}

The shoulder weight is only increased with increasing age in the carcasses of non-castrated lambs.
The edible portion of the shoulder of castrated lambs until 210 days old presented higher amount of lipids.

Castration positively influences the cholesterol content of the shoulder.

Castrated lambs presented higher concentrations of C 18:0, C18:1 T11, and CLA in the edible portion of the shoulder.

\section{References}

BONAGURIO, S.; PEREZ, J. R. O.; GARCIA, I. F. Composição centesimal de cordeiros Santa Inês puros e mestiços com Texel abatidos com diferentes pesos. In: SIMPÓSIO LATINO AMERICANO DE CIÊNCIA DE ALIMENTOS, 4., 2001, Campinas. Anais... Campinas: UNICAMP, 2001. p. 175.

BRASIL. Ministério da Agricultura. Departamento de Defesa e Inspeção Agropecuária. Decreto n 30.691, de 29 de março de 1952. Regulamento da Inspeção Industrial e Sanitária de Produtos de origem Animal - RIISPOA. Diário Oficial da República Federativa do Brasil, Brasília, DF, 01 de agosto de 1997.

CAÑEQUE, V. et al. The influences of carcass weight and Depot on the Fatty Acid Composition of Fats of Suckling Manchego lambs. Meat Science, v. 70, p. 373-379, 2005. http://dx.doi.org/10.1016/j. meatsci.2005.02.003

CHRISTIE, W. W. A simple procedure for rapid transmethilation of glycerolipids and cholesterol esters. Journal of Lipid Research, v. 23, p. 1072, 1982.

DOMINGUES, O. Introdução à zootecnia. 3. ed. Rio de Janeiro: Serviço de Informação Agrícola, 1968. 392 p.

Food and Agriculture Organization of the United Nations - FAO. FAOSTAT. 2008. http://faostat.fao.org/.

FOLCH, J.; LEES, M.; SLOANEY STANLEY, G. H. Simple method for the isolation and purification of total lipids from animal tissues. Journal of Biological Chemistry, v. 226, n. 1, p. 497, 1957.

FOOD AND AGRICULTURE ORGANIZATION - FAO. Food Outlook - June 2007. Disponível em: <http://www.fao.org/ docrep/010/ah864e/ah864e00.HTM>.

FREITAS, J. J. S.; KIETZER, K. S. Ácidos graxos e sistema nervoso. In: CURI, R.et al. Entendendo a gordura: os ácidos graxos. Manole: Barueri, 2002. $580 \mathrm{p}$.

GALLO, S. B.; SIQUEIRA, E. R.; ROSA, G. T. Efeito da nutrição da ovelha e do cordeiros sobre o perfil de ácidos graxos do músculo Tríceps brachii de cordeiros. Revista Brasileira de Zootecnia, v. 
36, n. 6, p. 2069-2073, 2007. Suplemento. http://dx.doi.org/10.1590/ S1516-35982007000900017

HARA, A.; RADIN, N. S. Lipid extraciton of tissues with low-toxicity solvent. Analitical Biochemistry, v. 90, p. 420-426, 1978. http:// dx.doi.org/10.1016/0003-2697(78)90046-5

HARTMANN, L.; LAGO, R. C. A. Rapid preparation of fatty acid methyl esters from lipids. Laboratory Practices, v. 22, p. 475-477, 1973.

HAYES, K. C. et al. Dietary saturated fatty acids (12:0, 14:0, 16:0) differ in the impact on plasma cholesterol and lipoproteins in nonhuman primates. American Journal of Clinical Nutrition, v. 53, p. 491498, 1991.

JOHNSON, D. D.; EASTRIDGE, J. S.; NEUBAUER, D. R. Effect of Sex class on Nutrient content of meat from Young Goat. Journal of Animal Science, v. 73, p. 296-301, 1995.

JONES, P. J. H.; KUBOW, S. Lipids, Sterols and their Metabolites. In: SHILS, M. E. (Ed.). Modern nutrition in health and disease. 9th ed. Baltimore: William's \& Wilkins, 2003. p. 71.

KEMP, J. D.; SHELLEY, J. M.; ELY, D. G. Effects of castration and slaughter weight on fatness, cooking losses and palability of lamb. Journal of Animal Science, v. 34, n. 4, p. 560-562, 1972.

MADRUGA, M. S. et al. Qualidade da carne de cordeiros Santa Inês terminados com diferentes dietas. Revista Brasileira de Zootecnia, v. 34, n. 1, p. 309-315, 2005. http://dx.doi.org/10.1590/S151635982005000100035

MAHGOUB, O. et al. Fatty acid composition of muscle and fat tissues of Oma ni Jebel Akhdar goats of different sexes and weights. Meat Science, v. 61, p. 381-387, 2002. http://dx.doi.org/10.1016/S03091740(01)00208-X

MAZALLI, M. R.; SALDANHA, T.; BRAGAGNOLO, N. Determinação de colesterol em ovos: comparação entre um método enzimático e um método por cromatografia líquida de alta eficiência. Revista Instituto Adolfo Lutz, v. 62, n. 1, p. 49-54, 2003.

MOLONEY, A. P. et al. Producing tender and flavoursome beef with enhanced nutritional characteristics. Proceedings of the Nutrition Society, v. 60, p. 221-229, 2001. http://dx.doi.org/10.1079/ PNS200077

MONTEIRO, E. M. Influência do cruzamento Ile de France $\times$ Corriedale (F1) nos parâmetros de qualidade da carne de cordeiro. 1998. 99 f. Tese (Doutorado em Ciência dos Alimentos)Universidade de São Paulo, São Paulo, 1998.

NASCIMENTO, C. M. O.; OYAMA, L. M. Long-chain polyunsacturated fatty acids essential for brain growth and development. Nutrition, v. 19, n. 1, p. 66-69, 2003. http://dx.doi.org/10.1016/S08999007(02)00955-3

OSÓRIO, J. C. S. et al. Efeito da castração sobre a produção de carne em cordeiros corriedale. Revista Brasileira de Agrociência, v. 5, n. 3, p. 207-210, 1999.

PÉREZ, J. R. O.; BRESSAN, M. C.; BRAGAGNOLO, N; PRADO, O. V.; LEMOS, A. L. S. C.; BONAGURIO, S. Efeito do peso de abate de cordeiros Santa Inês e Bergamácia sobre o perfil de ácidos graxos, colesterol e propriedades químicas. Ciência e Tecnologia de Alimentos, Campinas, v.22, n.1, p.11-18, jan./abr. 2002.

PÉREZ, J. R. O. et al. Efeito do peso de abate de cordeiros Santa Inês e Bergamácia sobre o perfil de ácidos graxos, colesterol e propriedades químicas. Ciência e Tecnologia de Alimentos, v. 22, n. 1, p. 11-18, 2002a.

PÉREZ, P. et al. Carcass characteristics and meat quality of suckling lambs. Suffolk Down breeds. Small Ruminant Research, v. 44, p. 233-240, 2002b. http://dx.doi.org/10.1016/S0921-4488(02)00076-7
PINHEIRO, R. S. B. Aspectos quantitativos da carcaça e qualitativos da carne de ovinos de diferentes categorias. 2006. 115 f. Dissertação (Mestrado em Zootecnia)-Faculdade de Ciências Agrárias e Veterinárias, Universidade Estadual Paulista, Jaboticabal, 2006.

REBELLO, F. F. P. Restrição alimentar na qualidade da carne de cordeiros. 2003. 125 f. Dissertação (Mestrado em Ciência dos Alimentos)-Universidade Federal de Lavras, Lavras, 2003.

RIBEIRO, E. L. A.; SILVA, L. D. F.; ROCHA, M. A.; MIZUBUTI, I. Y. Desempenho de cordeiros inteiros ou submetidos a diferentes métodos de castração abatidos aos $30 \mathrm{Kg}$ de peso vivo. Revista Brasileira de Zootecnia, Viçosa, v.32, n.3, p.745-752, 2003

SANTOS, C. L. Estudo do crescimento e da composição química dos cortes da carcaça de cordeiros Santa Inês e Bergamácia. 2002. 257 f. Tese (Doutorado em Zootecnia)-Universidade Federal de Lavras, Lavras, 2002.

SANTOS, C. L. Estudo do desenvolvimento, das características da carcaça e do cresimento alométrico de cordeiros das raças Santa Inês e Bergamácia. 1999. 143 f. Dissertação (Mestrado em Zootecnia)-Universidade Federal de Lavras, Lavras, 1999.

SANTOS-FILHO, J. M. et al. Effect of cashew nut suplemented diet, castration, and time of storage on fatty acid composition and cholesterol contento of goat meat. Small Ruminant Research, 57, p. 51-56, 2005. http://dx.doi.org/10.1016/j.smallrumres.2004.06.016

SCHAEFER, E. J.; BROUSSEAU, M. E. Diet, lipoproteins and coronary heart disease. Journal American Medical Association, v. 27, n. 3, p. 243-247, 1998.

SILVA, A. M. P. Avaliação da Carcaça, crescimento alométrico dos cortes e órgãos internos de cordeiros da raça Santa Inês em diferentes idades de abate. 2005. 57 f. Dissertação (Mestrado em Zootecnia)Universidade Estadual do Sudoeste da Bahia, Itapetinga, 2005.

SILVA, D. J. Análise de alimentos (métodos químicos e biológicos). Viçosa: UFV Imprensa Universitária, 1981. 166 p.

SILVA SOBRINHO, A. G. et al. Características de Qualidade da Carne de Ovinos de Diferentes Genótipos e Idades ao Abate. Revista Brasileira de Zootecnia, v. 34, n. 3, p. 1070-1076, 2005. http:// dx.doi.org/10.1590/S1516-35982005000300040

SIMOPOULOS, A. P. Omega-3 fatty acids in health and disease and in growth and development. American Journal of Clinical Nutrition, v. 54, n. 3, p. 438-463, 1991.

STATISTICAL ANALISYS SYSTEM INSTITUTE - SAS. SAS User $\mathbf{s}$ guide: Statistics. 5th ed. Cary: SAS Inst. Inc., 2000.

TEJEDA, J. F.; PEÑA, R. E.; ANDRES, A. I. Effect of live weight and sex on physico-chemical and sensorial characteristics of Merino lamb meat. Meat Science, v. 80, p. 1061-1067, 2008. http://dx.doi. org/10.1016/j.meatsci.2008.04.026

UAUY, R.; MENA, P.; VALENZUELA, A. Essential fatty acids as determinants of lipids requeriments in infants, children and adults. European Journal of Clinical Nutrition, v. 53, n. 1, p. 66-77,1999. http://dx.doi.org/10.1038/sj.ejcn.1600745

VELASCO, S. et al. Effect of different feeds on meat quality and fatty acid composition of lambs fattened at pasture. Meat Science, v. 66, p. 457-465, 2004. http://dx.doi.org/10.1016/S0309-1740(03)00134-7

VERGARA, H.; MOLINA, A.; GALLEGO, L. Influence of sex and staughter weight on carcass meat quality in light and medium weight lambs produced in intensive systems. Meat Science, v. 52, n. 2, p. 221-226, 1999. http://dx.doi.org/10.1016/S0309-1740(98)00171-5

ZEOLA, N. M. B. L. et al. Composição centesimal da carne de cordeiros submetidos a dietas com diferentes teores de concentrado. Ciência Rural, v. 34, n. 1, p. 253-257, 2004. http://dx.doi.org/10.1590/S010384782004000100039 